\title{
CHECK OF THE VALIDITY OF THE COMMON LABORATORY PROCEDURES USED FOR LUMINESCENCE DATING ON THE BASIS OF ALKALI FELDSPARS BY IR OSL SPECTRA
}

\author{
Galina HÜTT ${ }^{\mathrm{a}}$ and Ivar JAEK ${ }^{\mathrm{b}}$
}

\begin{abstract}
${ }^{a}$ Geoloogia Instituut (Institute of Geology), Estonia pst. 7, EE-0001 Tallinn, Eesti (Estonia)
${ }^{\mathrm{b}}$ Tartu Ülikooli eksperimentaalfüüsika ja tehnoloogia instituut (Institute of Experimental Physics and Technology, University of Tartu), Tähe 4, EE-2400 Tartu, Eesti (Estonia)
\end{abstract}

Presented by A. Raukas

Received 11 October 1995, accepted 3 June 1996

\begin{abstract}
Some common laboratory treatments used for luminescence dating of sediments on the basis of alkali feldspars were checked by infrared optically stimulated luminescence (IR OSL) spectra measurements. It was shown that preheating and measurements at elevated temperatures beginning from $80^{\circ} \mathrm{C}$ lead to a change of the IR OSL spectra due to the presence of the $\mathrm{Na}$ component in extracted alkali feldspars. These changes may cause underestimation of luminescence dates.
\end{abstract}

Key words: alkali feldspars, luminescence dating, palaeodosimetry, bleachability, preheating.

\section{INTRODUCTION}

The main requirement to all laboratory treatments of minerals which serve as palaeodosimeters is the undamaged character of their natural luminescence and dosimetrical properties.

The extraction of quartz and alkali feldspars from sediments includes the HF-etching procedure. For alkali feldspars this treatment was checked by Hütt et al. (1985) by measuring the thermoluminescence (TL) glow before and after etching. It was shown that the TL glow curve does not change in the temperature region from 200 to $400^{\circ} \mathrm{C}$. Some low temperature peaks, probably induced by surface defects, disappeared after etching.

Roberts et al. (1993, 1994) reported about cautions on the use of extended duration preheats of quartz for optical dating. 
Rendell et al. (1994) studied the influence of high temperature annealing (to $1000^{\circ} \mathrm{C}$ ) on luminescence properties of quartz measuring the TL glow and TL spectra before and after the procedure. Spectral changes, induced by a variety of thermal treatments, were observed in the TL of quartz. The procedure of laboratory calibration by the additive dose method was partly checked (Hütt et al., 1988) by measuring spectra stimulation of natural alkali feldspars after irradiation by additional doses up to $200 \mathrm{~Gy}$. There occurred no changes in the spectra: the same traps were revealed in the natural and laboratory irradiated alkali feldspars.

However, there are numerous procedures widely used as different ways of preheating (Smith et al., 1986; Rhodes, 1988; Godfrey-Smith et al., 1988; Stokes, 1992), light bleaching of samples with subsequent regeneration of the initial signal in a regeneration method, measurements at the temperatures which are lower (Bailiff \& Barnett, 1994) and higher (Duller \& Wintle, 1991; Mejdahl et al., 1992; Wiggenhorn, 1994) than room temperature. All these treatments may cause changes of luminescence or dosimetrical properties of minerals which are used as palaeodosimeters.

The validity of the above-mentioned laboratory procedures was checked by infrared optically stimulated luminescence (IR OSL) spectra measuring for alkali feldspars extracted from sediments.

\section{EXPERIMENTAL}

Alkali feldspars $(100-160 \mu \mathrm{m})$ were extracted from sediments of Scandinavia and Germany by a common technique (Mejdahl \& WintherNielsen, 1982). Calibration of samples was performed by gamma-source ${ }^{60} \mathrm{Co}$ with the dose rate of about $100 \mathrm{R} / \mathrm{min}$. Laboratory bleaching of samples was carried out by natural daylight or artificial sources of light, simulating sunlight.

Optical stimulation of luminescence was performed by an IR semiconductor laser $(860 \pm 1 \mathrm{~nm}$ ) with pulses of different length (from $3 \mathrm{~s}$ to some minutes). IR OSL spectra were measured with a CCD-camera based on the high sensitive spectrometer (Rieser et al., 1994). Spectra of IR OSL were not corrected: the idea was to compare IR OSL spectra before and after laboratory treatments.

\section{EXPERIMENTAL RESULTS AND DISCUSSION}

Natural IR OSL spectra of most of the studied alkali feldspars consist of two well resolved bands with the maximums at 410 and $570 \mathrm{~nm}$ (Fig. 1). The spectra did not change after laboratory calibration of a sample. These facts confirm the validity of the laboratory calibration procedure. 

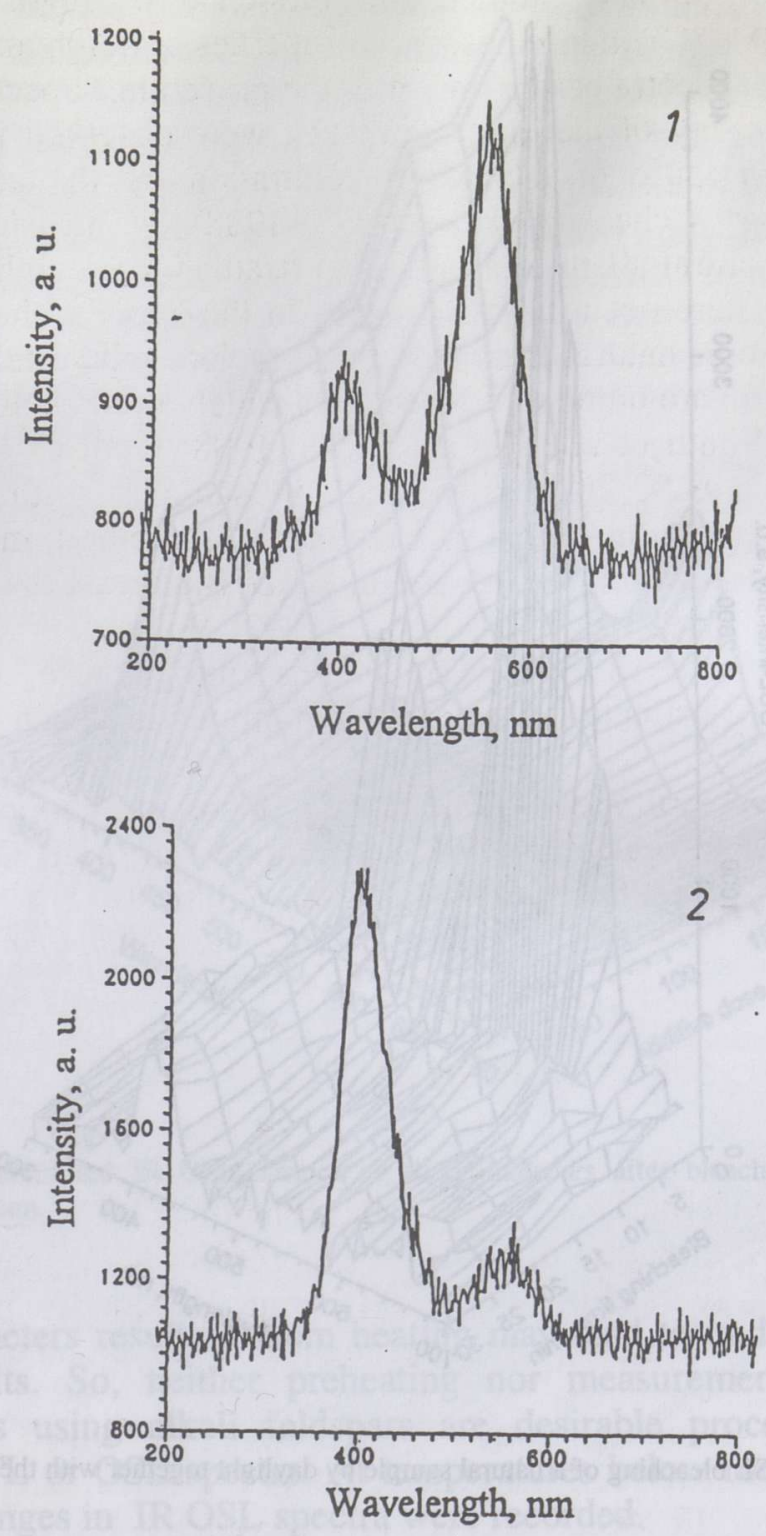

Fig. 1. IR OSL spectra of typical alkali feldspars extracted from Scandinavian sediments. 1, sample No. $986, K=10.0 \% ; 2$, sample No. $1022, K=11.8 \%$. Semiconductor laser $860 \pm 1 \mathrm{~nm}$ in pulse mode was used.

Regeneration technique OSL dating includes laboratory bleaching of samples with subsequent regeneration of initial signals by laboratory calibration. It was revealed that the orange band (at $570 \mathrm{~nm}$ ) was bleached faster and with a rather smaller residual than the blue band (Fig. 2). This peculiarity of orange emission is very promising for OSL dating because of more sure realization of the "z-point". After regeneration of the signal by laboratory dosing there were observed no changes in IR OSL spectra (Fig. 3). 


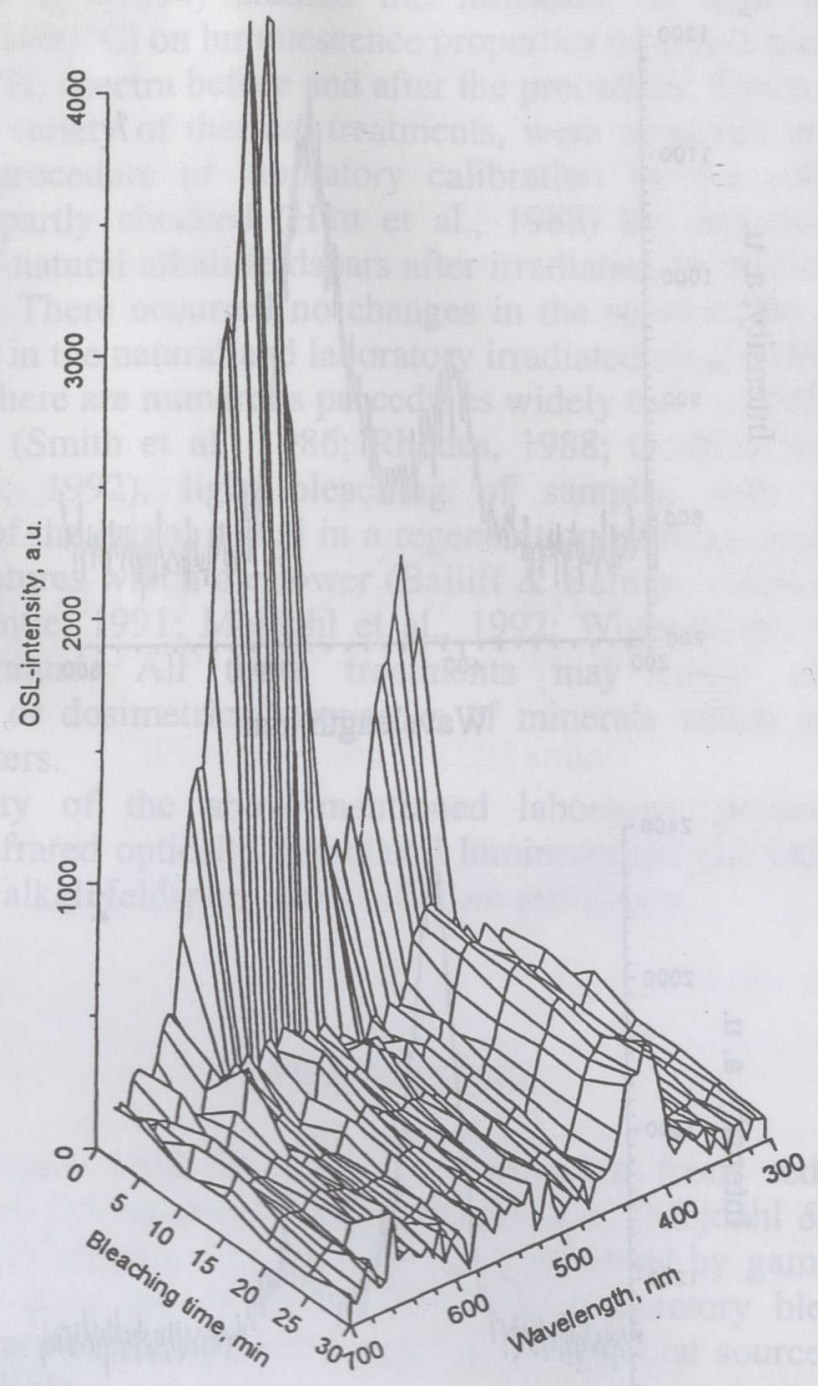

Fig. 2. Effect of OSL bleaching of a natural sample by daylight together with the UV component.

Rather widely used procedures such as preheating, measurements at elevated and below room temperatures were tested as well. IR OSL spectra were changed due to the redistribution of the orange and blue emission intensities at $80^{\circ} \mathrm{C}$. For the temperatures higher than $80^{\circ} \mathrm{C}$ strong interference between these two emission bands was observed (Fig. 4). This effect was revealed also after the preheating of irradiated samples beginning from $80^{\circ} \mathrm{C}$ for different lengths of time from $1 \mathrm{~min}$ to 1 hour and longer.

As shown by Hütt \& Jaek (1996), the doses reconstructed by blue emission are considerably larger than those obtained by using orange emission. It was supposed that hole stability at blue centra of recombination is higher than at orange centra. In this case changes of 


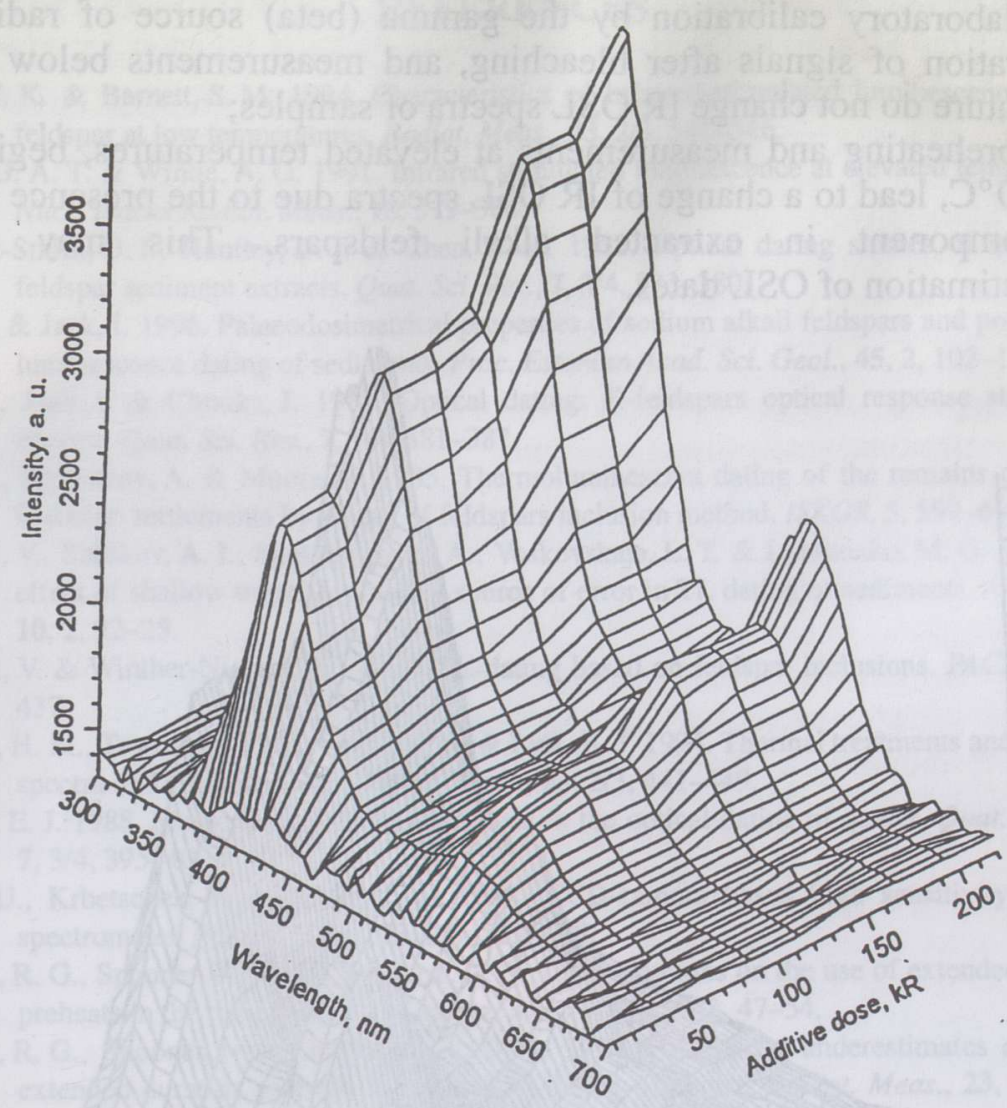

Fig. 3. Three-dimensional IR OSL spectra of alkali feldspars after bleaching and subsequent laboratory radiation.

palaeodosimeters resulting from heating may lead to underestimation of dating results. So, neither preheating nor measurements at elevated temperatures using alkali feldspars are desirable procedures without measuring TL or OSL spectra. At temperatures below room temperature no great changes in IR OSL spectra were recorded.

\section{SUMMARY}

Measurements of IR OSL spectra of alkali feldspars, extracted from sediments, yield important information about possible changes of their palaeodosimetrical properties after applying common laboratory treatments

The corresponding study performed in the Scandinavian region by applying routine luminescence dating laboratory treatments showed that: 
(a) laboratory calibration by the gamma (beta) source of radiation, regeneration of signals after bleaching, and measurements below room temperature do not change IR OSL spectra of samples;

(b) preheating and measurements at elevated temperatures, beginning from $80^{\circ} \mathrm{C}$, lead to a change of IR OSL spectra due to the presence of the $\mathrm{Na}$ component in extracted alkali feldspars. This may cause underestimation of OSL dates.

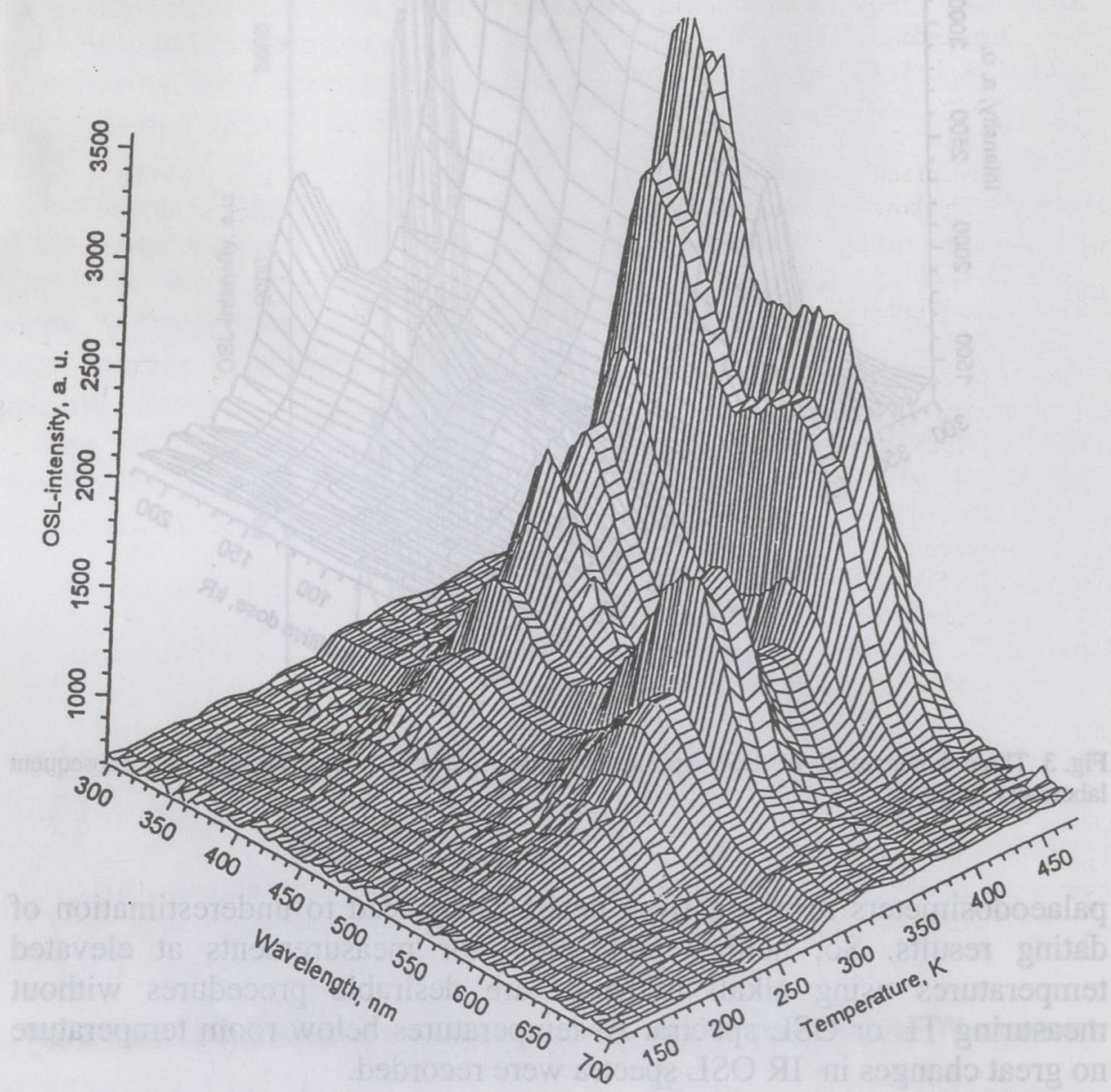

Fig. 4. Three-dimensional IR OSL spectra of alkali feldspars at low and elevated temperatures, sample No. 986.

\section{ACKNOWLEDGEMENTS}

G. H. acknowledges the financial support (COPERNICUS scholarship) of the Commission of European Communities, Estonian Science Foundation (Grant No. 325), and ISF (Grant No. LK7100). W. Stolz, U. Rieser, and M. Krbetschek are thanked for fruitful collaboration. 


\section{REFERENCES}

Bailiff, I. K. \& Barnett, S. M. 1994. Characteristics of infrared-stimulated luminescence from a feldspar at low temperatures. Radiat. Meas., 23, 2/3, 541-546.

Duller, G. A. T. \& Wintle, A. G. 1991. Infrared stimulated luminescence at elevated temperatures. Nucl. Tracks Radiat. Meas., 18, 379-384.

Godfrey-Smith, D. I., Huntley, D. J. \& Chen, W.-H. 1988. Optical dating studies of quartz and feldspar sediment extracts. Quat. Sci. Rev., 7, 3/4, 373-380.

Hütt, G. \& Jaek, I. 1996. Palaeodosimetrical properties of sodium alkali feldspars and problems of luminescence dating of sediments. Proc. Estonian Acad. Sci. Geol., 45, 2, 102-111.

Hütt, G., Jaek, I. \& Chonka, J. 1988. Optical dating: K-feldspars optical response stimulation spectra. Quat. Sci. Rev., 7, 3/4, 381-387.

Hütt, G., Molodkov, A. \& Moora, T. 1985. Thermoluminescent dating of the remains of ancient Estonian settlements by means of feldspars inclusion method. ISKOS, 5, 599-603.

Mejdahl, V., Shlukov, A. I., Shakhovets, S. A., Voskovskaja, L. T. \& Lyashenko, M. G. 1992. The effect of shallow traps: A possible source of error in TL dating of sediments. Ancient TL, 10, 2, 22-25.

Mejdahl, V. \& Winther-Nielsen, M. 1982. TL-dating based on feldspar inclusions. PACT, 6, 426437.

Rendell, H. M., Townsend, P. D., Wood, R. A. \& Luff, B. J. 1994. Thermal treatments and emission spectra of TL from quartz. Radiat. Meas., 23, 2/3, 441-449.

Rhodes, E. J. 1988. Methodological considerations in the optical dating of quartz. Quat. Sci. Rev., 7, 3/4, 395-400.

Rieser, U., Krbetschek, M. R. \& Stolz, W. 1994. CCD-camera based high sensitivity TL-OSL spectrometer. Radiat. Meas., 23, 2/3, 523-528.

Roberts, R. G., Spooner, N. A. \& Questiaux, D. G. 1993. Cautions on the use of extended duration preheats in the optical dating of quartz. Ancient TL, 11, 2, 47-54.

Roberts, R. G., Spooner, N. A. \& Questiaux, D. G. 1994. Palaeodose underestimates caused by extended-duration preheats in the optical dating of quartz. Radiat. Meas., 23, 2/3, 647653.

Smith, B. W., Aitken, M. J., Rhodes, E. J., Robinson, P. D. \& Gerald, D. M. 1986. Optical dating: Methodological aspects. Radiat. Prot. Dosim., 17, 229-233.

Stokes, S. 1992. Optical dating of young (modern) sediments using quartz: Results from a selection of deposition of environments. Quat. Sci. Rev., 11, 153-159.

Wiggenhorn, H. 1994. IR OSL dating of K-feldspar at elevated temperatures and infrared bleaching of TL. Radiat. Meas., 23, 2/3, 387-391.

\section{ÜLDKASUTATAVATE LABORATOORSETE PROTSEDUURIDE SEADUSPÄRASUSTE KONTROLL OPTILISELT STIMULEERITUD LUMINESTSENTSI MEETODIGA LEELISPÄEVAKIVIDE LUMINESTSENTSDATEERIMISEL}

\section{Galina HÜTT, Ivar JAEK}

On kontrollitud mõnede leelispäevakivide luminestsentsdateerimisel kasutatavate laboratoorsete protseduuride mõju saadavatele tulemustele. On näidatud, et eelkuumutamine ja mõõtmine kõrgendatud temperatuuril alates $80^{\circ} \mathrm{C}$ (seda tavaliselt kasutataksegi) põhjustavad muutusi optiliselt stimuleeritud luminestsentsi kiirgusspektrites, kuivõrd dateerimisel kasutatav setetest ekstraheeritud päevakivi kujutab endast $\mathrm{K}$ - ja $\mathrm{Na}$ komponentide segu. Need muutused võivad luminestsentsdateerimisel kaasa tuua vanuse alahindamise. 


\section{ПРОВЕРКА ПРАВОМЕРНОСТИ ОБЩЕПРИНЯТЫХ}

ЛАБОРАТОРНЫХ ПРОЦЕДУР, ИСПОЛЬЗУЕМЫХ ПРИ ЛЮМИНЕСЦЕНТНОМ ДАТИРОВАНИИ ОТЛОЖЕНИЙ

\section{НА БАЗЕ ЩЕЛОЧНЫХ ПОЛЕВЫХ ШПАТОВ, С ПОМОЩЬЮ СПЕКТРОВ ИК ОСЛ}

Галина ХЮТТ, Ивар ЯЭК

Проверена правомерность некоторых лабораторных процедур, широко используемых при люминесцентном датировании отложений на базе щелочных полевых шпатов путем измерения оптически стимулированных инфракрасным светом спектров люминесценции. Показано, что предварительный нагрев образцов и измерения при температурах свыше $80{ }^{\circ} \mathrm{C}$ вызывают необратимые изменения спектрального состава, поскольку экстрагированные из отложений полевые шпаты содержат и натриевый компонент. Эти изменения могут приводить к существенному омоложению люминесцентных датировок. 